\title{
Mobile telecommunication networks choice among Ghanaians
}

\author{
Boateng Henry* and Maapa Kwame Quansah
}

Department of Marketing and Customer Management, University of Ghana Business School, Ghana

\begin{tabular}{l}
\hline C H R O N I C L E \\
\hline Article history: \\
Received May 12, 2013 \\
Received in revised format \\
20 June 2013 \\
Accepted 25 June 2013 \\
Available online \\
June 27 2013 \\
\hline Keywords: \\
Mobile \\
Telecommunication \\
Networks \\
Choice
\end{tabular}
\begin{abstract}
A B S T R A C T
The paper investigates the factors influencing customers choice of telecommunication network in Ghana. The survey design was employed to enable the researchers perform statistical analysis. Questionnaire consisting of Likert scale question was used to collect the primary data. Multiple regression analysis was performed to ascertain the factors influencing customers' choice of telecommunication networks. The study found six factors that influence customers to choose a particular network. These factors include; brand awareness, brand image, perceived quality, price, convenience and brand loyalty. The study concludes that all the six factors contribute to the factors that drive consumer choice of telecommunications service in Ghana.
\end{abstract}

(c) 2013 Growing Science Ltd. All rights reserved.

\section{Introduction}

The spread of mobile technology has varied significantly between countries. While the majority of mobile subscribers inhabit developed countries, take-up of mobiles has accelerated in some developing countries (ITU, 1999). In 2008, statistics from the International Telecommunication Union revealed that the mobile phone subscribers currently constitute 60 percent of the world population (ITU, 2008a). The report also suggests that there are now more mobile phone users in the developing world than in the developed world. Consequently, the mobile communication industry is touted as one of the most competitive in Ghana (Boohene \& Agyapong, 2011). Scholars have linked the competitive and the vibrant nature of the sector to the deregulation (Boohene \& Agyapong, 2011; Frempong, 2002) and the recent mobile number portability facilitated by the government of Ghana.

In view of these developments, consumers have options - with about six telecommunication firms competing for their patronage. The National Communications Authority (NCA) - the body charged with the responsibility of registering, supervising and managing the country's telecom sector, has 
licensed six firms to operate in the country. They include: MTN, Millicom Ghana Ltd., Vodafone (Ghana), Expresso, Bharti Airtel and Globacom. Now, operators of the industry are faced with the challenge of demonstrating customer-focused and continuous service improvement than before, as a way to ensuring customer satisfaction, brand supremacy and ultimately customer loyalty (Boohene \& Agyapong, 2011). This explains the huge budgetary allocation of these companies for marketing communications, corporate social responsibility and sponsorship (Dolpin, 2003) with the ultimate aim of influencing customer network selection decisions.

Cole et al. (2008) posit that to make good decisions, customers must have information that is available, accurate, and timely, but they also have to be able to comprehend that information and its meaning. Further, they claimed that customers need to be able to determine meaningful differences between options and weight factors to match their needs and values, as well as being able to make trade-offs and ultimately to choose. Some scholars have expressed that customer knowledge, thoughts and feelings about a products or service affects customer choice of that product or service (Lai, 1995, Keller, 2009). This explains the investments such firms are making their brands.

Investing in a brand means that firms are endowing their offerings with unique attributes and associations to position these offerings positively in the minds of consumers in a manner that distinguish them from the offerings of competitors (Wheeler, 2003). The resultant of all branding activities is to help the firm or organization to endow its goods and/or services with positive brand equity (Ghodeswar, 2008). Thus when proper investments are made in the brand, customers develop favorable, unique brand associations that facilitate their choice of a brand (Aaker \& Joachimsthaler, 2000).

In this paper, we use the concept of consumer brand choice to study how Ghanaian mobile subscribers choose their mobile network. Hitherto studies have focused on different aspects of the subject. Tong et al. (2009) notes that most brand choice research works have focused on the manufacturing sector. In fact, various scholars have discussed the issue of brand choice in various discussions on branding. For instance, Aaker (1996) saw brand choice as a tool for building strong brands while Nilson (2000) studied it as an added value for competition. Keller (2003) on his part discussed it as an element of brand equity. de Chernatony (2006) studied brand choice in the context of services branding and Kapferer (2008) looked at it from the sustained brand equity point of view.

Interrogating the literature, Alamro and Rowley (2011) argue that the aforementioned scholars failed to put the concept of brand choice at the centre of their discussions. They further claim studies on brand choice are scattered across time, sector and places; and eventually developed a grand model for the discussion on brand choice which tested fourteen hypotheses as antecedents of brand choice. Yet Almaro and Rowley (2011) concede that Singh et al. (2005) were right to call for more research into brand preference and its antecedents since their work could not put the debate rest.

In Ghana, there is paucity of knowledge regarding consumer brand choice. However, recent developments show a growing interest in the issue of consumer brand choice. A useful example is the classic work of Narteh et al. (2012) who studied drivers of automobile brand choice. Another Ghanaian study on consumer brand choice is the work of Agyapong and Kobina (2012). Their study is close to the current research as they both relate to brand choice. However, they fail to review literature on brand choice. They argue service quality as antecedent to customer satisfaction and fail to show any conceptual link the two constructs have with brand choice. Our position is that Agyapong and Kobina (2012) did not address their research objective heralded in the brand choice concept. This is because brand choice is a pre-purchase issue whiles customer satisfaction is both service consummation experience and post purchase evaluation. Consequently, we conduct this research to fill the gap of insufficient understanding of what influences mobile network selection among Ghanaian users of mobile communication services. 


\section{Literature Review and Research Framework}

Bertilsson (2009) opines that firms ascribe important characteristics to brands to serve as strategic business assets in their quest to achieve relevant competitiveness on the market. Central to branding is customer's ability to identify a product or its category from those of competitors (Aaker, 1991; Kotler \& Keller, 2009, Koehn \& Bertilsson, 2009). According to De Chernatony and McDonald (2003) brands go beyond the physical components of what they stand for to encompass additional attributes which are important considerations for consumers' buying decisions.

The next section discusses relevant issues that culminate into the motives of the brand choice concepts after which the conceptual framework is developed.

\section{Motives of Brand Choice}

The extant literature indicates that a consumer's intention to buy a specific brand not only depends on the attitude toward the target brand but also on the attitude toward competing brands (Laroche et al.,1996). This can be defined as a predisposition to respond in a favorable way to competitor's brands (Burton et al., 1998) and has been shown to positively influence the percentage of products purchased (Garretson et al., 2002; Burton et al., 1998). After gleaning through the literature, certain factors were found to influence consumer brand choice and these are subsequently discussed in the following subsections.

\subsection{Brand Awareness}

Researchers such as Narteh et al (2012) and Jiang (2004) agree that brand awareness is an element that plays a vital role in consumer brand choice. Keller (2009) views brand awareness as related to the strength of the brand node or trace in memory, as reflected by consumers' ability to identify the brand under different conditions. Thus, brand name awareness regards the extent to which a brand comes to mind and the ease at which it does so. Thus, in simple terms, brand awareness is about how easy it is for the brand to be remembered (Narteh et al., 2012). Kotler (2009) intimate that brand awareness comprises brand recall and brand recognition. Brand recall he defined as consumer's ability to retrieve the brand when given the product category, the needs fulfilled by the category, or some other type of probe as a cue. Regarding brand recognition, he defined it as consumers' ability to confirm prior exposure to the brand when given the brand as a cue (Keller, 2008, 2009).

Esch et al. (2006) assert that customer - based brand equity occurs when the consumer is aware and familiar with the brand and holds positive associations about the brand in memory. Keller (2009) extends this argument by stating that consumers attribute certain associations with a brand only when they have high level of brand awareness and familiarity with the brand. He further posits that since consumers spend little time or effort on the consumption decision of low involvement products, brand awareness alone is sufficient to decide consumer brand choice and determine purchase as consumers are willing to base their choices merely on familiar brands. Laverie et al. (2008) also argued that brand awareness is an important component of brand equity across all conceptualizations of the construct for products (Keller, 1993) and for services (Kayaman \& Arasli, 2007).

Reflecting the salience of the brand in the customers mind, awareness can be assessed at several levels such as recognition, recall, top of mind, brand dominance (the only brand recalled), or, even more, brand knowledge (what the brand stands for is very well known by consumers) (Aaker, 1996). Brand awareness is argued as the crucial first stage of buyer readiness (Strong, 1925; Puth, 2000; Brassington and Pettitt, 2000) and a key prerequisite dimension of the entire brand knowledge system in consumers' minds, reflecting their ability to identify the brand under different conditions; the 
likelihood that a brand name will come to mind and the ease with which it does so (Keller, 1993) in order to encourage a customer to develop a preference and thus move closer to the point of purchase. Not only that awareness is almost a prerequisite for a brand to be included in the consideration set (the brands that receive consideration for purchase), but it also influences perceptions and attitudes, and can be a driver for brand loyalty (Aaker, 1991).

In Lin and Chang (2003), the result of their study established that brand awareness had the most powerful influence on consumers purchase decision. Hoyer and Brown (1990) as cited by Lin and Chang (2003) in their study examined the importance of brand awareness in consumers' decision making process and they found out that brand awareness was a primary factor. Also Jiang (2004) found out in his study that brand recognition influences consumer's choice.

\subsection{Brand Image}

Brand image is seen as one key motive of consumer brand choice by marketing professionals. Brand image is described as the perceptions and beliefs held by consumers about a brand (Kotler and Keller (2009). Much earlier, Keller (1993) had postulated brand image as a type of brand associations that consumers hold in memory. Brand associations are defined by three dimensions: attributes (nonproduct related and product-related), benefits (functional, experiential and symbolic) and attitudes toward the brand (Keller, 2009). It may also be viewed as consumer perceptions of a brand as reflected by the brand associations held in consumers' memory (Keller, 2008). Other scholars view it as the combined effect of brand association or consumers perception of the brands tangible and intangible association (Engel et al., 1995).

According to Low and Lamb (2000), brand image can also be referred to as the emotional perception or reason that consumers place to a particular brand. Thus, brand image does not exist in the features, technology or the actual product itself, it is perceptual (Pappu et al., 2005; Tasci et al., 2007) and brought out by advertisement, promotion or users. Brand image provides the benefit of lower purchase risks, enables a consumer to recognize a product, evaluate product quality and obtain certain experience and satisfaction out of product differentiation (Kwon, 1990; Lassar et al., 1995). Researchers have proposed that brand equity is to an extent driven by the brand association composition of the image.

Keller (1993), Lasser (1995) and Aaker (2003) agree that favorable, unique and strong associations are assumed to provide positive brand image which create a bias in the mind of consumers thereby increasing the brand equity. The definition of $\mathrm{CBBE}$ does not distinguish sources of brand associations and the manner in which they are formed (Keller, 2009). This however means that consumers can form brand associations in a variety of ways other than marketing activities. Thus, from direct experience; through information from other commercial or nonpartisan sources such as consumer reports or other media vehicles; from word of mouth; and by assumptions or inferences consumers make about the brand itself, its name or logo (Keller, 2009). In addition, it could also be its identification with a company, country, and channel of distribution, or person, place or event (Keller, 2009). Brand managers against this backdrop, are advised to recognize the influences of these other sources of information by both managing them as well as possible and by adequately accounting for them in designing communication strategies (Aaker, 1996).

When the customer experiences that the brand is delivering the benefits that it promises, brand bonding occurs (Kotler \& Keller, 2009). Aaker (2003) calls this brand loyalty and means customers' resistance to switching is increased regarding brands that are unknown. On the basis of this, Narteh et al. (2012) assert that the "brand's image becomes the compass of its identity, pointing towards the place where it can leverage the most power in the category in which it competes and establish the most powerful influence within the lives of its potential users" (p. 517). 
Krishnan (1996) found out that brands with high brand equity are prone to more positive brand associations than those with low brand equity. Also Lassar et al (1995) found out that brands with high brand image rating always have higher brand equity and premium price. Conclusively, Kwon (1990) reported that positive brand image is mostly likely associated with preferred brands, a position which Aaker (2003) shares.

Drawing lessons from above, it is obvious that the perceived brand image of a particular brand will be a key driver of consumer brand choice as the perceived brand image reflects the meaning consumers ascribe to a particular brand. Thus, the more consumers have strong, unique and favorable associations with a particular brand, the more these consumers are likely to choose it as a preferred choice as these associations give consumers a compelling reason for choosing the brand.

\subsection{Perceived Quality}

Branded products are further expected to show evidence of greater quality compared to non-branded products, and premium brands should display even greater levels of quality (Woodside and Ozcan, 2009; Bhat and Reddy, 1998). A majority of consumers are usually of the expectation that in order to be satisfied and delighted, then there should be an acceptable correlation between the price they pay for their choice of brands and the utmost quality associated with the brand (Quelch, 1987). This is because branded products (i.e. either manufacturer brands or national brands) represent a set of promises to consumers (Keller, 1993). Woodside and Ozcan (2009) argue that higher prices for branded products are justified by consumers' quality assumptions that come with the brand name. Thus, it is argued here that perceived quality of the brand influences consumer choice. Consumers therefore will ultimately choose a particular brand if they perceive that brand to be quality.

\subsection{Brand Loyalty}

Brand loyalty has been described as both a behavioral response and a function of psychological processes (Jacoby \& Kyner, 1973). Thus brand loyalty is a function of both attitudes and behavior (habit). In addition to brand attitudes and habit, which are brand specific, the concept of brand loyalty represents a general concept which describes a consumer's overall buying behavior patterns within a product class (Day, 1969). It is a descriptive variable that refers to individual differences in consumers' general shopping behavior and buying styles within a particular product class. Brand loyalty is defined here as a consumer's preference to buy a single brand name in a product class; it is a result of the perceived quality of the brand and not its price. Brand loyalty leads to greater and continual sales since the same brand is repeatedly purchased, irrespective of situational constraints.

Also, consumers may use more of the brand to which they are loyal, since they may "like" using the brand or because they identify with the image of the brand. Brand loyal consumers are willing to pay more for a brand because they perceive some unique value in the brand that no other alternative can provide. Lastly, brand loyal users are willing to search for a brand and they require less advertising frequency, resulting in lower costs for advertising and distribution.

\subsection{Convenience}

Another area that has been of immense interest with regards to literature on consumer brand decision making is the convenience with which consumers are able to obtain their choice of brands which is referred to as accessibility. Research on consumer memory and choice has been dominated by paradigms that implicitly assume the availability of the brand, whether it is physically present in the choice situation or symbolically present in working memory as a member of a stable evoked set of brands in a product category. Research attention, therefore, typically has focused on the accessibility 
of brand information, given the presence of the brand. Recently, brand accessibility has attracted some attention, but only from the perspective that the product category is the stimulus activating brand retrieval processes (Alba et al., 1991).

Considering Farquhar's (1989) approach of brand equity, there was an accessible attitude he refers to and this is related to how quickly a consumer can retrieve brand elements stored in his/her memory (brand awareness). The attitude activation is sometimes - automatic (it occurs spontaneously upon the mere observation of the attitude object) and sometimes - controlled (the active attention of the individual to retrieve previously stored evaluation is required). It was also proven (Farquhar, 2000) that only high accessible attitudes (brands with a high level of awareness) can be relevant when purchasing or repurchasing a brand.

\subsection{Price}

The price elasticity of demand for a particular brand from a consumer's perspective is one of the main determinants of the purchase decision as it is an easy way to compare alternative product and services. Empirical evidences that price affects consumer choice of the service have been found (Nowlis \& Simonson (2000). Bateson (1995) and Gabbott \& Hogg (1998) reached the same conclusion from a conceptual point of view. Generally, consumers are willing to pay higher prices for brands that they perceive to have high value (Erdem \& Swait, 1998) as the brand reflects the product/service quality. As a result, it could be concluded that the price of the brand represents a source of information about the product/service; hence, it affects and simplifies the consumer's brand selection process (Teas \& Grapentine, 1996).

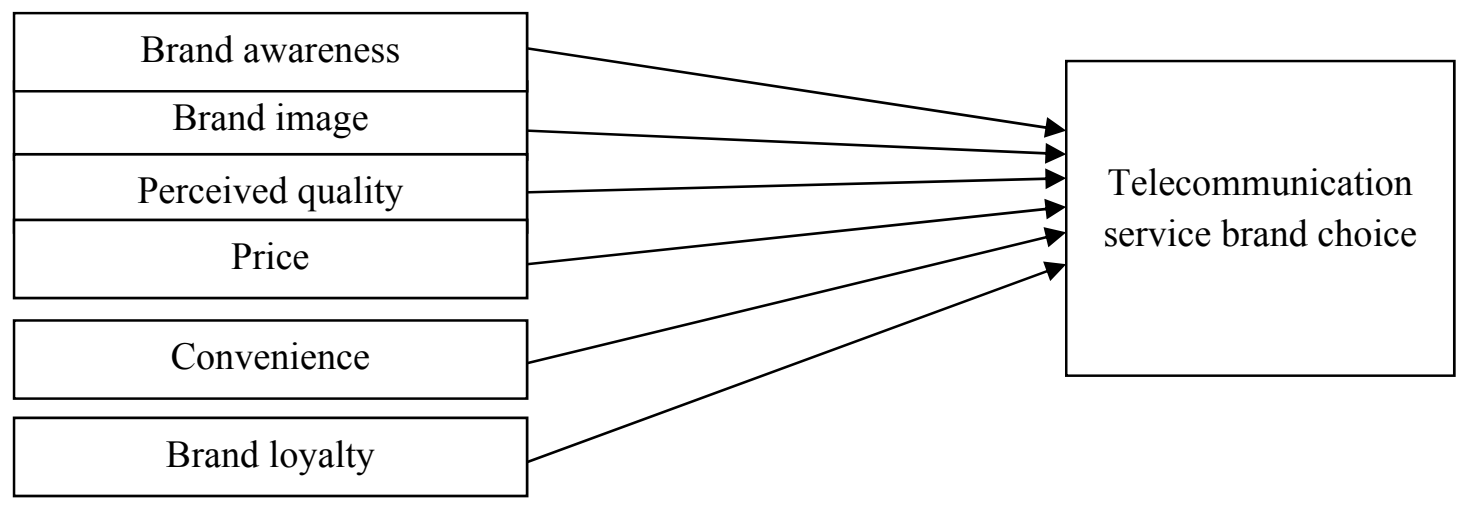

Fig. 1. Conceptual Framework for Key Motives of Consumer Brand Choice (Source: Adapted from: Aaker, 1991; Keller, 2003; Nowlis \& Simonson, 2000)

\section{Research Methodology}

The study employed the survey strategy using questionnaires to investigate the motivation for telecommunications network selection in Ghana. A structured questionnaire with close-ended questions was developed to gather the data. The questionnaire was divided into two main sections: Section A and B. Section A sought to obtain information about the personal characteristics of the respondents sampled for the study. Section B contained questions that sought to identify and assess the key drivers influencing consumer brand choice of telecommunications networks in Ghana. For the drivers of consumer brand choice the questions were in five-point Likert scale, with options: 1= Strongly Disagree, 2= Disagree, 3= Neither Agree Nor Disagree, 4= Agree and 5= Strongly Agree, where respondents were required to indicate their level of agreement with motives of telecommunication networks. 
The convenience sampling method was used to select a sample size of 200. The appropriateness of the 200 respondents is justified by Neuman (2007) who asserts that when it comes to sampling size selection the researcher should use his discretion. In addition, this decision is consistent with by Tabacknick and Fidell (1996) who suggested that, for a regression analysis, the minimum sample size (N) should be $\mathrm{N}>50+8 \mathrm{M}$, where $\mathrm{M}$ is the number of predictors (independent variables).. In this study, there are 6 main predictors of telecommunication network brand choice as contained in the conceptual framework adapted for this study (i.e. brand awareness, brand image, perceived quality, price, convenience and brand loyalty), thus the sample size based on their recommendation should be greater than 98 .

Convenient sampling technique, which attempts to obtain a sample of convenient elements (Malhotra, 2007) was used to select the final sample of 200. This was found appropriate due to the difficulty in identifying customers who have visited the customer care centres. In addition, Nueman (2007) notes this form of sampling is cheap, time saving and as the name suggests, it is the most convenient method of sampling. Therefore, customers were intercepted as they were leaving the customer care centres of the telecommunications companies after being served by the employees. This was done to reduce the limitations posed by convenient sampling.

\subsection{Data Analysis, interpretation and results}

Respondents for the survey were profiled in accordance with their sex, age, educational background and their choice of telecommunication network. All 200 questionnaires distributed were salvaged and filled in the presence of the researchers and all of them were found usable.

The sample consisted of $58.9 \%$ male and $41.1 \%$ female. Regarding their age, majority representing $34.3 \%$ of the respondents were within the ages of 29-39 years of the entire sample. This was followed by those within the age range of $18-28$ years, who accounted for $30.2 \%$. Respondents within the age ranges of 40-50 and 51-61 years constituted $16.7 \%$ and $16.7 \%$ of the entire sample respectively, while respondents above 61 years recorded $2.1 \%$. Respondents had varying educational backgrounds. However, respondents with Degree accounted for $52.6 \%$ of the total number of respondents. This was followed by respondents with Diploma and Postgraduate degree recording 22.4\% and 9.9\% respectively, while Senior High/General Certificate of Education Ordinary Level (GCE "O" Level) backgrounds accounted for 5.7\%. Respondents with Vocational/Technical certificates recorded 3.1\%., while those with General Certificate of Education, Advanced Level (GCE "A" Level) and Junior High/Middle School, recorded 2.6\% and 2.6\% respectively. Respondents with primary school educational background also constituted $1.0 \%$. Findings from this study indicate that majority $(37.0 \%)$ of sampled respondents used more than one telecommunication network. This was followed by $20.0 \%$ respondents who used MTN network alone. Tigo and Airtel users only recorded $14.7 \%$ and $9.9 \%$ respectively, while Vodafone users only also contributed $9.4 \%$. Expresso users only were found to be the minority constituting $1 \%$ of respondents. Table 1 provides the results of the other demographic statistics obtained from the study.

\subsection{Initial Consideration}

Prior to the extraction of factors, the Bartlett test of Sphericity (sig. 0.000) and the KMO measure of sampling adequacy (Value of .903) confirmed that there was significant correlation among the variables to warrant the application of exploratory factor analysis. KMO overall statistic of .903 obtained gives an indication that there is a higher possibility of the existence of an inter-correlation between the variables thereby making them sensible for analysis. In addressing the reliability of scales in respect of independent variables, Cronbach Alpha was applied at a significant level of zero (0). Per the results obtained, the Cronbach's Alpha coefficient for all the scales for the independent 
variables exceeded the conventional acceptable figure of 0.7 . The high alpha values indicate good internal consistency among the variables, and the high alpha value for the overall scale indicates that the convergent validity of the model is met and thus proved to be reliable for multiple regression analysis.

\section{Table 1}

Demographic Profile of respondents

\begin{tabular}{|c|c|c|}
\hline \multirow[t]{2}{*}{ Profile of respondents } & \multicolumn{2}{|c|}{ Sample composition } \\
\hline & $n$ & $\%$ \\
\hline \multicolumn{3}{|l|}{ Gender } \\
\hline Male & 118 & 58.9 \\
\hline Female & 82 & 41.1 \\
\hline \multicolumn{3}{|l|}{ Age } \\
\hline $18-28$ & 60 & 30.2 \\
\hline $29-39$ & 69 & 34.3 \\
\hline $40-50$ & 33 & 16.7 \\
\hline $51-61$ & 33 & 16.7 \\
\hline Above 61 & 4 & 2.1 \\
\hline \multicolumn{3}{|l|}{ Education } \\
\hline Post Graduate & 20 & 9.9 \\
\hline Degree & 105 & 52.6 \\
\hline Diploma & 45 & 22.4 \\
\hline 'A' Level & 5 & 2.6 \\
\hline SHS/`O’ Level & 11 & 5.7 \\
\hline Vocational/Technical Certificate & 6 & 3.1 \\
\hline JHS & 5 & 2.6 \\
\hline Primary & 2 & 1 \\
\hline No education & 0 & 0 \\
\hline \multicolumn{3}{|l|}{ Network Selected } \\
\hline Multiple users & 74 & 37 \\
\hline MTN & 56 & 28 \\
\hline Vodafone & 29 & 9.4 \\
\hline Tigo & 20 & 14.7 \\
\hline Airtel & 19 & 9.9 \\
\hline $\begin{array}{l}\text { Expresso } \\
\text { Note: } n=200\end{array}$ & 2 & 1 \\
\hline
\end{tabular}

\subsection{Multiple Regression Analysis}

A multiple regression was used to analyze the relationship between consumer brand choice and its drivers. This was done to extract the independent variables that better explain the dependent variable. Consumer brand choice was used as the dependent variable whilst the independent variables were represented by brand awareness, brand image/positioning, perceived quality, price, convenience and brand loyalty. Table 2 presents a summary of the multiple regression least squares results for the dependent and independent variables.

Table 2

Multiple regression analysis for drivers of consumer brand choice

\begin{tabular}{lllll}
\hline Variable & Beta & S.E & T & Prob. \\
\hline Constant & & .161 & .089 & 0.00 \\
Brand awareness & .198 & .027 & 2.548 & 0.02 \\
Brand image/positioning & .429 & .057 & 7.121 & .000 \\
Perceived quality & .395 & .028 & 4.196 & .000 \\
Price & .313 & .021 & 4.232 & 0.00 \\
Convenience & .746 & .025 & 7.159 & 0.00 \\
Brand loyalty & .079 & .027 & 2.225 & .020 \\
\hline
\end{tabular}


Table 3

Regression analysis for over all model

\begin{tabular}{ll}
\hline S.E of estimates & .72674 \\
R-Square & .600 \\
Adj. R-Square & .589 \\
F-statistics & 55.521 \\
Prob. (F-stats.) & .000 \\
\hline
\end{tabular}

The regression (prediction) equation on the above model can be presented as follows:

$\mathrm{CBC}=\alpha+.198 \mathrm{Ba}+.429 \mathrm{Bi}+.395 \mathrm{Pq}+.313 \mathrm{P}+.746 \mathrm{C}+.079 \mathrm{Bl}+\mathrm{E}$

where:

$\mathrm{CBC}=$ Consumer Brand Choice, $\alpha=$ Constant, $\mathrm{Ba}=$ Brand awareness, $\mathrm{Bi}=$ Brand image, $\mathrm{Pq}=$ Perceived quality, $\mathrm{P}=$ Price, $\mathrm{C}=$ Convenience, $\mathrm{Bl}=$ Brand loyalty, $\mathrm{E}=$ Error term

The above results implies the model can be used to predict future consumer brand choice in the Ghanaian telecommunication industry, once the values/scores of brand awareness, brand image, perceived quality, price, convenience and brand loyalty are known.

\subsection{Evaluation of the Model}

The results indicate that there is a strong and significant reliability between variables used for the model to represent consumer brand choice in the telecommunication industry and its drivers $(\mathrm{F}=$ 55.521, Prob. F-stats <0.05). Some research scholars (such as Costello and Osborn, 2005 and Field, 2005) argue that the model reaches statistical significance if the Sig $<.05$. In this study the $\mathrm{Sig}=.000$ of the F-statistics depicts that the model is statistically significant. The R-Square value in the model summary depicts the degree of variance in the dependent variable which is explained by the model (including the independent variables). From the table, it can be found that $\mathrm{R}$ Square value $=.600$. Expressed as a percentage, it is found that the model consisting of independent variables (brand awareness, brand image, perceived quality, price, convenience and brand loyalty) explains $60.0 \%$ of the variance in consumer brand choice in the Ghanaian telecommunication industry, an important indication of the relevance of the model. This provides partial support for the proposed model. By implication, creating and managing strong telecommunication network brands can have an important role to play in the telecommunication industry (Chen, 2008). From the regression analysis results, convenience was found to have the greatest influence on consumer brand choice of a telecommunication network $(\beta=.746, \mathrm{t}=7.159, \mathrm{p}=0.000<0.05)$. This means that consumers of telecommunication network consider to a large extent convenience of the services of telecommunication network providers such as telecommunication service centers widely located in many communities, telecommunication network chips widely available and telecommunication network reload voucher widely distributed.

The next strongest contributor to telecommunication network brand choice is brand image/positioning $(\beta=.429, \mathrm{t}=7.121, \mathrm{p}=0.000,<0.05)$ implying that consumers of telecommunication networks choose telecommunication networks because it is perceived to possess unique features, it is prestigious, it has a wider coverage area, and because all their friends and relatives use it. This is to assert that consumers in Ghana merely patronize a telecommunication network brand just because it is positioned to possess a particular image. This is congruent with some previous studies (such as Pitta \& Katsanis, 1995) who have postulated the indispensable role played by a brand's image on consumers when making purchase decisions. According to Sullivan (1998), brands themselves may 
possess an image that consumers find desirable and as such most companies spend large amounts of money attempting to shape the image of their brands and products.

The third motive behind the Ghanaian customers' choice of a telecommunication network brand is perceived quality $(\beta=.395, \mathrm{t}=4.196, \mathrm{p}=0.000,<0.05)$. The study reveals the extent to which perceived quality issues such as the reliability of a telecommunication network, employees of telecommunication network's ability help customers when they need help, and how skillful and knowledgeable employees these telecommunication networks are all influence telecommunication network consumer's brand choice of a telecommunication network in Ghana.

Additionally, price (operationalized as services of network lowly priced, services of network highly priced and consumers getting value for money from services provided by the network providers) was the fourth motive considered by consumers of telecommunication networks in Ghana $(\beta=.313$, $\mathrm{t}=$ 4.232, $\mathrm{p}=0.000,<0.05)$. This finding seems to confirm empirical evidences that price affects consumer choice of the services (Nowlis \& Simonson, 2000; Bateson, 1995; Gabbott \& Hogg, 1998). Generally, consumers are willing to pay higher prices for brands that are perceived as high value (Erdem \& Swait, 1998) as the brand reflects the product/service quality. As a result, it could be concluded that the price of the brand represents a source of information about the product/service; hence, it affects and simplifies the consumer's brand selection process (Teas \& Grapentine, 1996).

Brand awareness was found to be the fifth motive that influences Ghanaian telecommunication network consumers' brand choice of the telecommunication network $(\beta=.198, \mathrm{t}=2.548, \mathrm{p}=0.02,<$ 0.05). This means that consumers usually choose telecommunication network brands which are within their evoked set considerations; this usually created by marketing activities such as intensified advertising, PR, and promotions. This confirms Keller (1993) assertion that, the brand awareness plays an important role in the decision process of consumer. In congruence with previous studies on brand awareness (Woodside \& Wilson, 1985; Rossiter \& Percy 1987), it is fair to further posit that for a consumer to choose a telecommunication network brand, they must first have an intense knowledge of it. Brand attitude cannot be formed, and intention to buy cannot occur unless brand awareness has occurred and has accentuated to the consumer's evoked set. Finally, brand loyalty (operationalized as consumers being happy with their service, consumers purchasing new products developed by the network service providers, and consumers continuing to use their network's services even if competing brands offer similar services) ) was the last motive considered by consumers of telecommunication networks in Ghana $(\beta=.079, \mathrm{t}=2.225, \mathrm{p}=0.020,<0.05)$. This also confirms Keller (2003)'s assertion that, consumers may use more of the brand to which they are loyal, since they may "like" using the brand or because they identify with the image of the brand.

\section{Conclusions and managerial implications}

Prior to this study, our understanding of the drivers of consumer brand choice in the telecommunication industry was not clear. Consequently the conceptual framework developed proposed that telecommunication consumers' brand choice is results from six key factors: brand awareness, brand image, perceived quality, price, convenience and brand loyalty. The study concludes that all the six factors contribute to the factors that drive consumer choice of telecommunications service in Ghana. Thus, confirming the propositions made in the conceptual framework. Moreover, findings suggest that, the convenience dimension $(\beta=.746, t=7.159$, $\mathrm{p}=0.000<0.05$ ), has greater influence on consumer choice of telecommunications brands in Ghana. This is followed by brand image/positioning $(\beta=.429, \mathrm{t}=7.121, \mathrm{p}=0.000,<0.05)$ and perceived quality $(\beta=.395, \mathrm{t}=4.196, \mathrm{p}=0.000,<0.05)$ respectively. These were identified as the three most influential drivers of consumer brand choice in the telecommunications industry of Ghana. One remarkable impact of the deregulation of Ghana's telecommunications industry is the intense competition which arose due to the many new entrants into the sector. The findings of this study provide useful information for management of telecommunication firms who are striving lead the 
competition by improving on the brand equity. Thus, it is recommended that management of telecommunication firms undertake the following measures:

- Establish customer service centres at strategic locations and ensure even distribution of chips and reload vouchers for the convenience of customers

- Ensure effective positioning and create positive image for their brand and

- Institute measure to ensure timely delivery of services

This study contributes to existing literature on brand choice by extending it to the telecommunication industry. This study focused on the general description of the key drivers of consumer brand choice in the telecommunication industry. Since the industry comprises six key players, it will be good for future studies to compare the strength of these brands. Again, the concept of consumer brand choice can be studied in other industries or products such as mobile phone, transport, healthcare and education. It must also be born in mind that samples were drawn from customers located in Accra. Meanwhile, the customers of telecommunication firms are spread across the entire country. The study is thus, limited in terms of geographical coverage. However, since the service conditions are similar, these findings could be a representation of the views of entire Ghanaians. Subsequent studies need to increase the sample size to empirically establish these findings.

\section{Acknowledgements}

We are thankful to Nii Quaye and his colleagues for their support. We are also grateful to all who helped us in the data collection.

\section{References}

Aaker, D. (1991). Managing Brand Equity. Capitalizing on the Value of a Brand Name. Free Press: New York.

Aaker, D. (1996). Building Strong Brands. Free Press: New York.

Appiah-Gyimah, R., Boohene R., A., Agyapong Gloria, K. Q, \& Boohene, K. (2011). Customer satisfaction in the outdoor advertising industry: A case of alliance media Ghana limited. International Journal of Marketing Studies, 3(2), 82-91

Alamro, A., \& Rowley, J. (2011). Antecedents of brand preference for mobile telecommunications services. Journal of Product \& Brand Management, 20(6), 475 - 486.

Bateson, J. E. G. (1991). Managing Services Marketing (2nd Ed.). The United States of America: The Dryden Press

Bertilsson, J. (2009). The Way Brands Work; Consumers' Understanding of the Creation and Usage of Brands. Lund Business Press, Lund.

Bhat, S., \& Reddy S.K. (1998). Symbolic and functional positioning of brands. Journal of Consumer Marketing, 15(1), 32-43.

Boohene, R., \& Agyapong, G. K. Q. (2011). Analysis of the antecedents of customer loyalty of telecommunication industry in Ghana: The case of Vodafone (Ghana). International Business Research, 4(1), 229-240.

Cole, C., Laurent, G., Drolet, A., Ebert, J., Gutchess, A., Lambert-Pandraud, R. ,Mullet, E., Norton, M. I., \& Peters, E. (2008). Decision making and brand choice by older consumers. Marketing Letters, 19(3-4), 355-365.

De Chernatony, L., \& McDonald, M. (2003). Creating Powerful Brands, $3^{\text {rd }}$ ed., Elsevier, Amsterdam.

Erdem, T., \& Swait, J. (1998). Brand equity as a signaling phenomenon. Journal of Consumer Psychology, 7, 131-57.

Esch, F.R., Langner, T., Schmitt, B.H., \& Geus, P. (2006). Are brands forever?. Journal of Product \& Brand Management, 15(2), 98-105. 
Farquhar, P. H., Herr, P. M., \& Fazio, R. H. (1990). A relational model for category extensions of brands. Advances in Consumer Research, 17(1), 856-860.

Farquhar, P., \& Yuji, I. (1993) A Dialogue on Momentum Accounting for Brand Management. International Journal of Research in Marketing, 1, 77-92.

Frempong, G. (2002). Telecommunication Reforms-Ghana's Experience National Communication Authority. Ghana National Telecom Policy. 2005.

Gabbott, M., \& Hogg, G. (1998). Consumers and Services, John Wiley and Sons, Chicester

Hoyer W.D and Brown, S. P (1990).Effects of brand awareness on choice for a common, repeat purchase product. Journal of Consumer Research, 17, 141-148.

ITU-T .(2010). Ghana telecommunication data statistics.

Jiang, P. (2004). The role of brand name in customization decisions: a search vs experience perspective. Journal of Product \& Brand Management, 13(2), 73-83.

Krishnan, H. S. (1996). Characteristics of memory associations: A consumer-based brand equity perspective'. International Journal of Research in Marketing, 13, 389-405.

Keller, K.L. (1993). Conceptualizing, measuring and managing customer-brand equity. Journal of Marketing, 57 (1), 1-22.

Keller, K. (2003). Brand synthesis: the multidimensionality of brand knowledge. Journal of Consumer Research, 29, 595-600.

Kotler, P., \& Keller, K.L. (2009). Marketing Management, $13^{\text {th }}$ ed., Pearson Education, Upper Saddle River, NJ.

Kwon, Y. (1990).Brand name awareness and image perception of women's daytime apparel. Perceptual and Motor Skills, 71, 43-52.

Lai, A. W. (1995). Consumer Values, Product Benefits and Customer Value: A Consumption Behavior Approach. in Advances in Consumer Research Vol 22, eds. Frank R. Kardes and Mita Sujan, Advances in Consumer Research Vol 22 : Association for Consumer Research, 381-388.

Lassar, W., Mittal, B., \& Arun, S. (1995). Measuring customer-based brand equity. Journal of Consumer Marketing, 12(4), 11-19.

Lin, M.Y., \& Chang, L.H. (2003). Determinants of habitual behavior for national and leading brands in China. Journal of Product \& Brand Management, 12, 94-107.

Malhotra, N., \& Birks, D. (2007), Marketing Research: An Applied Approach, Prentice Hall, London.

Narteh, B., Odoom, R., Braimah, M., \& Buame, S. (2012). Key drivers of automobile brand choice in sub-Saharan Africa: the case of Ghana. Journal of Product \& Brand Management, 21(7), 516528.

Nimako, S. G., Azumah, F. K., \& Donkor, F. (2010). Overall customer satisfaction in Ghana's mobile telecommunication networks: Implications for management and policy. ATDF Journal, 7(3/4), 3549.

Nowlis, S.M., \& Simonson, I. (2000). The role of explanations and need for uniqueness in consumer decision making: unconventional choices based on reasons. Journal of Consumer Research, 27(1), 49-68.

Quelch, J.A. (1987). Marketing the premium product. Business Horizons, 30 (3), 38-45.

Singh, V. P., Hansen, K. T., \& Gupta, S. (2005). Modeling preferences for common attributes in multicategory brand choice. Journal of Marketing Research, 42 (May), 195-209.

Tabachnick B.G., \& Fidell L.S. (1996). Using Multivariate Statistics, $3^{\text {rd }}$ ed., New York: HarperCollins College Publishers, Inc.

Teas, K., \& Grapentine, T. (1996). Demystifying brand equity. Marketing Research 8(2) 24-30.

Wheeler, A. (2003). Designing Brand Identity, a Complete Guide to Creating, Building, and Maintaining Strong Brands. John Wiley \& Sons, Inc.

Woodside, A.G., \& Ozcan, T. (2009). Customer choices of manufacturer versus retailer brands in alternative price and usage contexts. Journal of Retailing and Consumer Services, 16(2), 100-108. 